\title{
Cadmium and copper reduce hematopoietic potential in common carp (Cyprinus carpio L.) head kidney
}

\author{
Elzbieta Kondera $\cdot$ Malgorzata Witeska
}

Received: 30 August 2012/ Accepted: 12 October 2012/Published online: 20 October 2012

(C) The Author(s) 2012. This article is published with open access at Springerlink.com

\begin{abstract}
The effects of cadmium and copper on activity of common carp head kidney hematopoietic tissue were evaluated. The fish were subjected to short-term ( $3 \mathrm{~h}, \mathrm{Cd}-\mathrm{s}$ and $\mathrm{Cu}-\mathrm{s})$ or long-term (4 weeks, $\mathrm{Cd}-1$ and $\mathrm{Cu}-\mathrm{l}$ ) exposures to $100 \%$ $96 \mathrm{hLC}_{50}$ or $10 \% 96 \mathrm{hLC}_{50}$, respectively. Head kidneys were isolated weekly from 5 fish of each group for 4 weeks (post-short-term exposure and during long-term exposure). Percentage of early blast cells among the hematopoietic precursors was calculated. Proliferative and apoptotic activity were evaluated using immunocytochemical staining for proliferating cell nuclear antigen (PCNA) and caspase 3, respectively. Hematopoietic activity was calculated as the ratio of proliferating to apoptotic cells. All metal exposures induced an increase in frequency of early blast cells. The frequency of proliferating (PCNApositive) cells also significantly increased. A considerable and significant increase in the frequency of apoptotic cells was the most pronounced effect of metal exposures. Both short-term and long-term treatments caused similar effects, but in case of $\mathrm{Cd}$ exposures, the reaction was more pronounced. All metal exposures reduced hematopoietic potential of fish measured as the ratio of proliferating to apoptotic
\end{abstract}

E. Kondera · M. Witeska ( $\bowtie)$

Department of Animal Physiology, University of Natural

Sciences and Humanities, Prusa 12, 08-110 Siedlce,

Poland

e-mail: wites@ap.siedlce.pl; wites@uph.edu.pl precursor cell frequency. However, in all cases, hematopoietic activity was higher than 1 showing that the rate of repair of hematopoietic tissue prevailed over destruction.

Keywords Carp - Hematopoiesis · Fish .

Proliferation · Apoptosis · PCNA · Caspase 3

\section{Introduction}

In most teleost fishes head kidney, pronephros plays an important role as main hematopoietic organ and blood cell reservoir (Fange 1994; Houston et al. 1996; Fijan 2002a, b; Romano et al. 2002; Moritomo et al. 2004; Rombout et al. 2005; Gangopadhyay and Homechaudhuri 2011). According to Wendelaar Bonga (1997) and Weyts et al. (1999), pronephros shows not only hematopoietic activity but also is a lymphoid and endocrine organ. However, head kidney is not the only site of hematopoiesis in fish. According to various authors (Glomski et al. 1992; Houston et al. 1996; Kobayashi et al. 2006, 2007, 2008; Zapata et al. 2006; Mulero et al. 2007 and Santos et al. 2011), other organs such as spleen, gut-associated lymphoid tissue (GALT), mucosa-associated lymphoid tissue (MALT), and intertubular tissue of trunk kidney (mesonephros) may also show hematopoietic activity. In some fish species, several hematopoietic organs are active, while in the others only one of them (Liu et al. 2004; Mulero et al. 2007; Patel et al. 2009). 
Morphology of hematopoietic tissue in fish is quite well known (e.g., Fange 1994; 2002a, b), but little information is available on the effects of environmental factors on its structure and activity, and studies of hematopoietic tissue are seldom included in evaluation of physiological effects of toxic agents on fish. Hematopoietic activity of head kidney tissue involves proliferation of stem cells and early precursors of all cell lines, differentiation and maturation, as well as apoptosis, and the rate of all these processes is a key factor that determines efficiency of hematopoiesis. Stem cell renewal and precursor cell proliferation are counterbalanced by apoptosis in functionally inactive or terminally differentiated cells (McKenna and Cotter 1997). Apoptosis plays an important role in regulating early progenitor and stem cells, and particularly for the development and function of lymphoid cells (Domen 2000). Cell proliferation involves the presence of PCNA - proliferating cell nuclear antigen — a protein found only in cells undergoing mitosis. The marker protein of apoptosis is caspase 3-an enzyme participating in degradation of nuclear and cytoplasmic proteins during this process. This caspase is commonly defined as effector caspase (Migliarini et al. 2005). Evaluation of both precursor cell proliferation and apoptosis rate is applied in hematological studies to evaluate the rate of cell turnover and hematopoietic activity (Thiele et al. 1997; Kvasnicka et al. 1999). The presence of PCNA in fish hematopoietic tissue was confirmed by Leung et al. (2005) for Danio rerio. Both fish PCNA and caspase 3 have been proved to react with mammalian (mouse or rabbit) monoclonal antibodies, and these antibodies were successfully used for evaluation of proliferation and apoptosis of various cells in Thalassoma pavo (Monteiro et al. 2009), Oreochromis niloticus (Brunelli et al. 2011), and Salmo salar (Yousaf et al. 2012).

Cadmium and copper are well known to induce hematotoxicity in fish, often resulting in anemia and immunosuppression (e.g., Svobodova et al. 1994; Dethloff et al. 1999; Vosyliene 1999; Joshi et al. 2002; Drastichova et al. 2004; Seong-Gil et al. 2004; Ates et al. 2008; Witeska et al. 2009, 2010). Sometimes the values of hematological parameters of intoxicated fish fluctuate, and their changes are not always directly related to metal concentrations and time of exposure or time post-exposure (Ruparelia et al. 1990; Shah and Altindag 2005; Witeska et al. 2010). These fluctuations may result from translocation of cadmium and
Table 1 Water quality parameters during the experiment

\begin{tabular}{llll}
\hline Parameter & Group & & \\
\cline { 2 - 4 } & $\mathrm{C}$ & $\mathrm{Cu}-\mathrm{s}+\mathrm{Cu}-1$ & $\mathrm{Cd}-\mathrm{s}+\mathrm{Cd}-1$ \\
\hline $\begin{array}{c}\text { Temperature } \\
\left({ }^{\circ} \mathrm{C}\right)\end{array}$ & $17.0 \pm 0.5$ & $17.1 \pm 0.5$ & $17.2 \pm 0.6$ \\
$\begin{array}{l}\text { Hardness }(\mathrm{mg} / \\
\mathrm{dm}^{3}\end{array}$ & $179-198$ & & \\
$\left.\mathrm{CaCO}_{3}\right)$ & & & \\
$\mathrm{pH}$ & $6.8-7.0$ & & \\
$\mathrm{O}_{2}\left(\mathrm{mg} / \mathrm{dm}^{3}\right)$ & $8.9 \pm 0.6$ & $9.0 \pm 0.2$ & $8.8 \pm 0.5$ \\
$\mathrm{NO}_{2}{ }^{-}\left(\mathrm{mg} / \mathrm{dm}^{3}\right)$ & $0.03 \pm 0.01$ & $0.06 \pm 0.02$ & $0.04 \pm 0.02$ \\
$\mathrm{NH}_{4}{ }^{+}\left(\mathrm{mg} / \mathrm{dm}^{3}\right)$ & $3.9 \pm 0.6$ & $5.2 \pm 0.8$ & $6.1 \pm 1.6$ \\
\hline
\end{tabular}
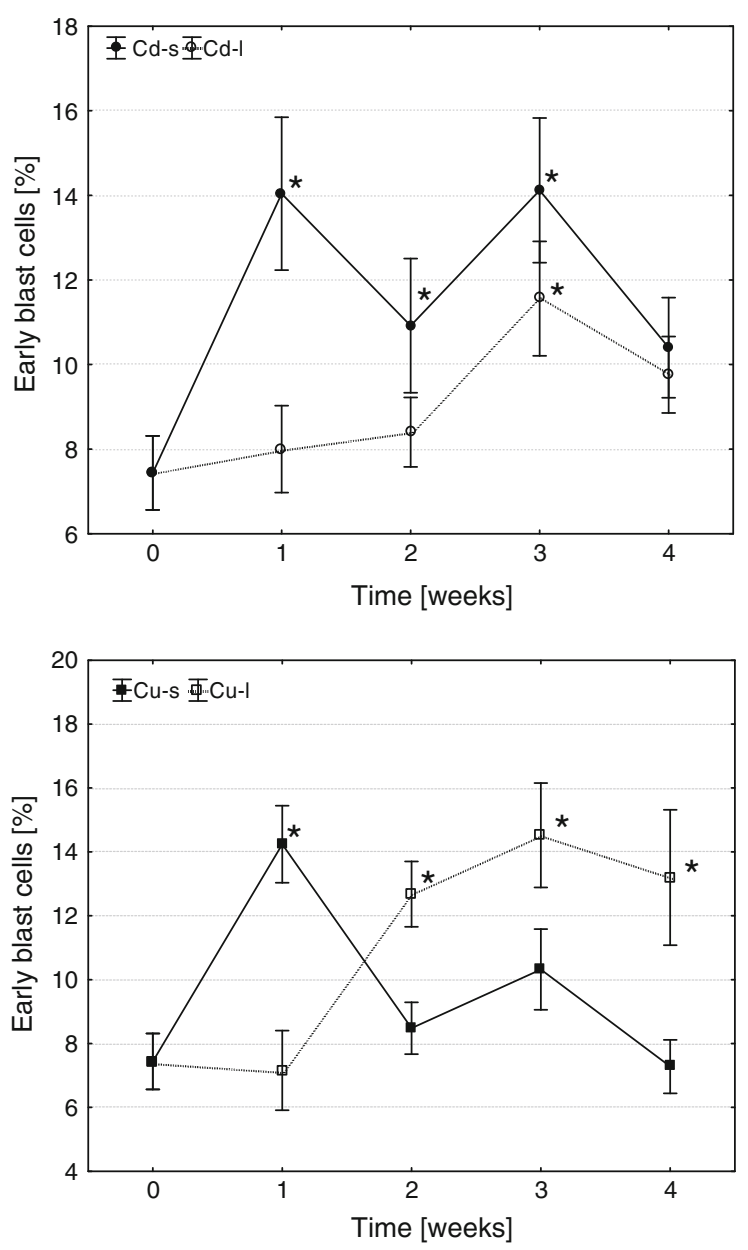

Fig. 1 The effects of $\mathrm{Cd}$ and $\mathrm{Cu}$ on the frequency of early blast cells in head kidney hematopoietic tissue of common carp (arithmetic mean \pm s.e., *different from the value before metal exposure (time 0 ), $p \leq 0.05$, U Mann-Whitney test). Cd-s, Cu-s and $\mathrm{Cd}-1, \mathrm{Cu}-\mathrm{l}$-groups subjected to short- or long-term exposures, respectively 
copper within the organism, and their toxic action on various functions at different time. Cadmium and copper probably affect not only circulating blood cells, but also newly developing ones in hematopoietic tissue. Very scarce data concerning hematopoietic effects of heavy metals in fish (Garofano and Hirshfield 1982; Ghosh et al. 2007; Som et al. 2009) and mammals (Lutton et al. 1984; Mitsumori et al. 1998; Van Den Heuvel et al. 1999; 2001; Celik et al. 2005, 2009) indicate that they are cytotoxic to precursor cells, and various cell lineages show different sensitivity to metal toxicity.

The aim of present study was to evaluate the effects of copper and cadmium under various exposure conditions (concentration and time) on hematopoietic potential of common carp head kidney.

\section{Materials and methods}

Common carp (Cyprinus carpio L.) 6-month-old juveniles of body mass $21.5 \pm 8.3 \mathrm{~g}$ were harvested in October from the rearing ponds of the Inland Fisheries Institute in Żabieniec and brought to the Department of Animal Physiology, University of Natural Sciences and Humanities in Siedlce in plastic bags with water and supplied with pure oxygen. Before the experiment, the fish were acclimated for 4 weeks to the laboratory conditions in the flow-through tank, at $17-18{ }^{\circ} \mathrm{C}$. Water was constantly aerated, and $\mathrm{O}_{2}$ concentration was $6.1-8.0 \mathrm{mg} / \mathrm{dm}^{3}$ of $\mathrm{O}_{2}$ (66-87\% saturation), while concentration of $\mathrm{NO}_{2}{ }^{-} 0.02-0.06 \mathrm{mg} / \mathrm{dm}^{3}$, and $\mathrm{NH}_{4}{ }^{+}$ $4.6-7.1 \mathrm{mg} / \mathrm{dm}^{3}$. The fish were fed Aller Aqua Classic $4 \mathrm{~mm}$ feed at the rate of $2 \%$ of stock mass per day. Prior to the experiment survival tests were performed, and $96 \mathrm{hLC}_{50}$ values were calculated using the probit method for both metals. Fish were exposed for $3 \mathrm{~h}$ to $\mathrm{Cd}$ and $\mathrm{Cu}$ concentrations equal to $100 \%$ of $96 \mathrm{hLC}_{50}$ (6.50 and $0.75 \mathrm{mg} / \mathrm{dm}^{3}$ for $\mathrm{Cd}$ and $\mathrm{Cu}$, respectively) - groups $\mathrm{Cd}$ $\mathrm{s}$ and $\mathrm{Cu}-\mathrm{s}$ or for 4 weeks to $10 \%$ of $96 \mathrm{hLC}_{50}(0.65$ and $0.075 \mathrm{mg} / \mathrm{dm}^{3}$, respectively)_groups $\mathrm{Cd}-1$ and $\mathrm{Cu}-1$. Control group (C) was kept in clean tap water $\left(<0.3-1 \mu \mathrm{g} / \mathrm{dm}^{3}\right.$ of $\mathrm{Cd}, 2-33 \mu \mathrm{g} / \mathrm{dm}^{3}$ of $\left.\mathrm{Cu}\right)$. Experimental solutions were made using $\mathrm{CdCl}_{2} \times 2 \frac{1}{2} \mathrm{H}_{2} \mathrm{O}$ and $\mathrm{CuSO}_{4} \times 5 \mathrm{H}_{2} \mathrm{O}$, and $3 / 4$ was renewed everyday without disturbing fish. The fish were kept in $100 \mathrm{dm}^{3}$ aerated tanks (10 fish in each), and fed Aller Aqua Classic $4 \mathrm{~mm}$ (1\% of stock mass, once a day before water renewal). Five fish were sampled weekly for 4 weeks from each experimental group and killed for head kidney isolation. Water quality parameters were measured everyday (Table 1) using portable DO meter (HANNA instruments HI 9143), pH meter (ELWRO PRL TN 5123), and kits for nitrogen metabolites (Visocolor ${ }^{\circledR}$ ammonium $0,2-10 \mathrm{mg} / \mathrm{dm}^{3}$ and Visocolor ${ }^{\circledR}$ nitrite $0,05-2 \mathrm{mg} / \mathrm{dm}^{3}$, Machery Nagel). Water

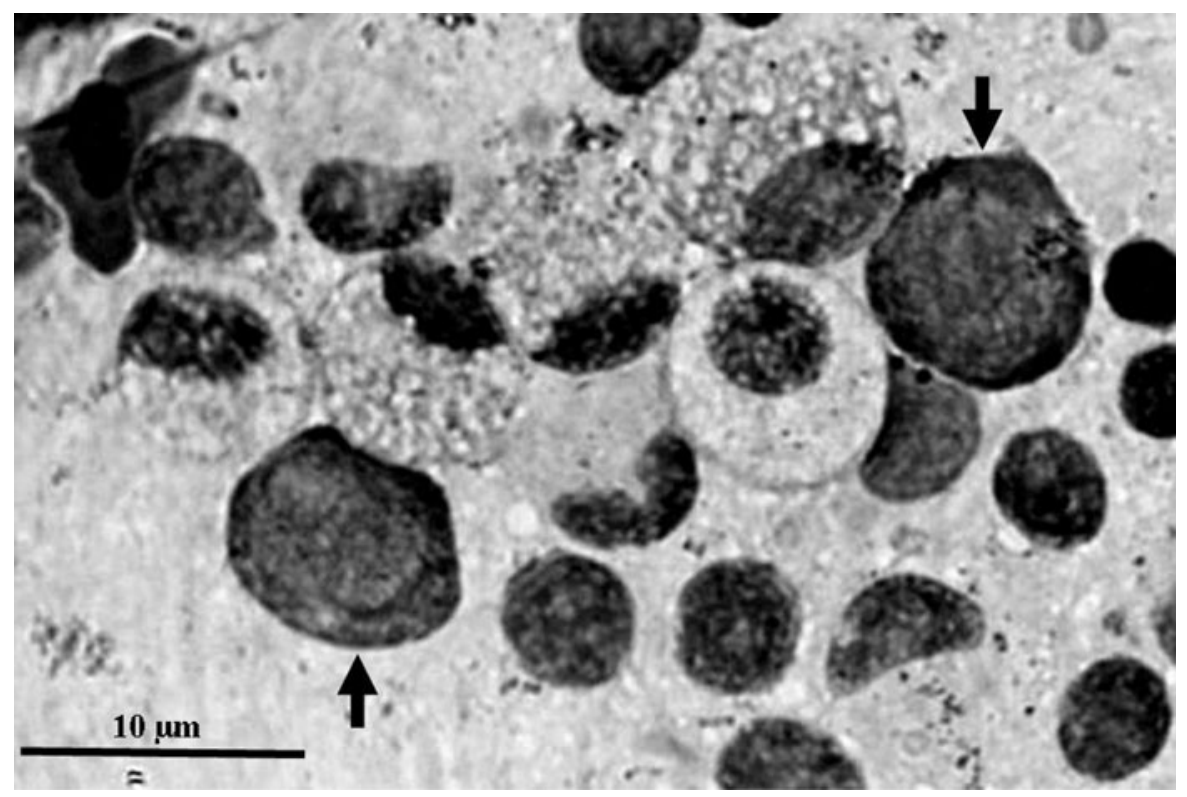

Fig. 2 Early blast cells 
hardness values were provided by the water supplier (www.pwik.siedlce.pl).

Five fish were sampled weekly for 4 weeks from each experimental group and killed for head kidney isolation. The kidneys were sliced and smeared on degreased slides and dried at room temperature for $24 \mathrm{~h}$. Two preparations from each fish were stained Giemsa and May-Grunwald for cytological analysis. Hematopoietic precursor cells were identified (22 types of cells, according to Fijan 2002a, b, and Kondera 2011). Percentage of early blast cells was calculated per 500 cells in each preparation.

Immunocytochemical staining was also performed to identify proliferating cells (showing PCNA), and cells undergoing apoptosis (showing caspase 3 ) using monoclonal mouse antibodies anti-proliferating cell nuclear antigen clone PC 10 (Dako Cytomation) selectively binding to the PCNA antigen, and anti-Caspase 3 (active) antibody produced in rabbit, (Sigma) binding to active caspase 3 . Dried preparations were hydrated with deionized water, and then peroxidase activity was blocked using $3 \% \mathrm{H}_{2} \mathrm{O}_{2}$ (Trace Pur, Merck). The antibody solution diluted 1:300 was applied and left on slides for $1 \mathrm{~h}$ at room temperature. Cells with antibodyprotein complexes were visualized using Dako Cytomation En Vision + System-HRP for use with mouse primary antibodies, and Dako Cytomation En Vision + System-HRP for use with rabbit primary antibodies, respectively, according to the producer's instruction. The PCNA-positive and caspase 3-positive cells stained brownish and were easily distinguishable from other cells (stained light blue with hematoxylin). Negative control staining was also performed (the preparations were treated the same way except for incubation with antibodies) and resulted in no color reaction. The cells were counted in at least 6 fields, and percentage of proliferating and apoptotic cells was calculated per 300 cells in each preparation.

All preparations were preserved with Histokitt, Glaswarenfabrik Karl Hecht GmbH Germany, covered with cover glass, and viewed using Nikon Eclipse E600 microscope at $1,000 \times$ magnification. Photographs were done using Nikon-Eclipse E600 microscope connected with digital Nikon Coolpix camera and computer image analysis system CoolView (Precoptic, Poland).

The results were subjected to statistical evaluation of significance of differences in values of all parameters between the control and metal-exposed groups using Mann-Whitney U test (Statistica 9.0) at $p \leq 0.05$.
The study obtained agreement of the III Local Ethical Committee at the Warsaw University of Life Sciences (No 41/2008).

\section{Results}

Both metals induced significant changes in frequency of blast cells, as well as proliferating and apoptotic precursors. Short-term exposures to $\mathrm{Cd}$ and $\mathrm{Cu}$ resulted in an increase in the frequency of early blast cells in head kidney of carp in 1 week after the treatments (Figs. 1, 2). The level of blasts in Cd-s fish remained significantly
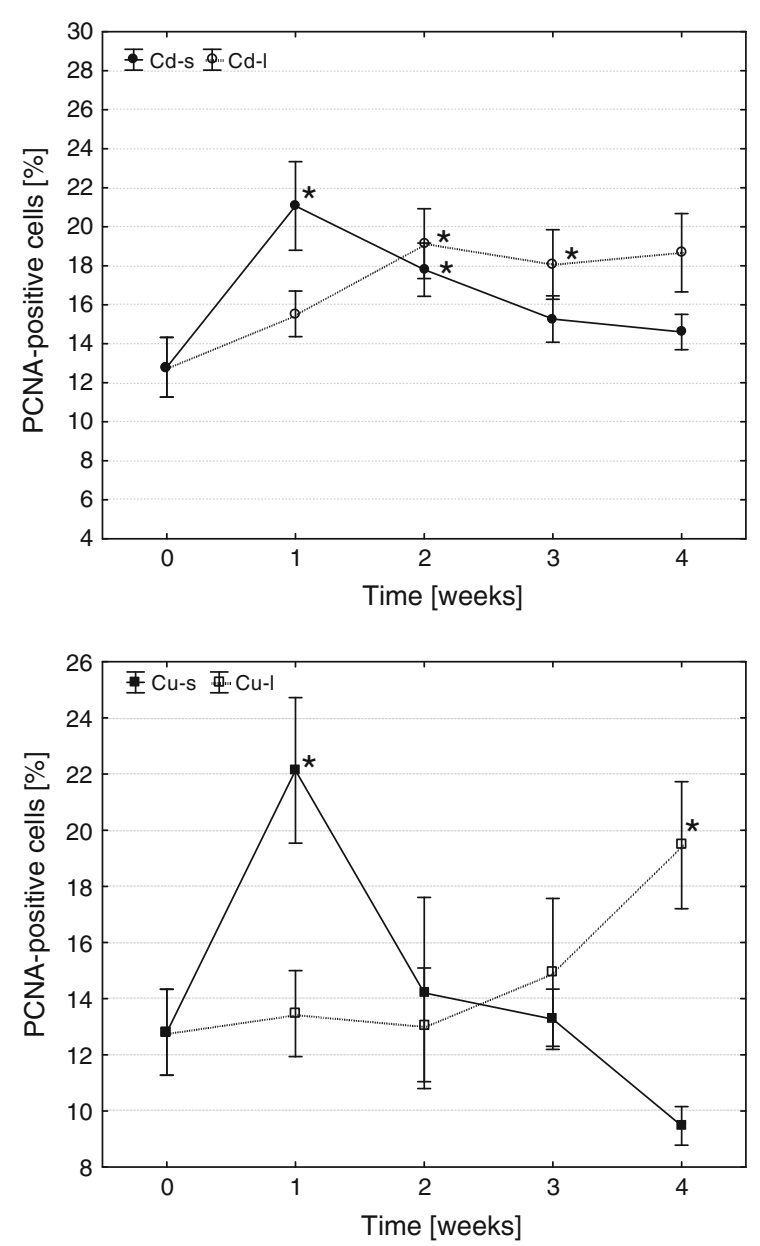

Fig. 3 The effects of $\mathrm{Cd}$ and $\mathrm{Cu}$ on the frequency of proliferating cells in common carp head kidney hematopoietic tissue (arithmetic mean \pm s.e., *different from the value before metal exposure (time 0 ), $p \leq 0.05$, U Mann-Whitney test). Cds, $\mathrm{Cu}-\mathrm{s}$ and $\mathrm{Cd}-1, \mathrm{Cu}-\mathrm{l}$ - groups subjected to short- or long-term exposures, respectively 
elevated until the 3-week post-exposure, while in $\mathrm{Cu}$-s group decreased already in the 2 weeks. On the contrary, during long-term exposure, $\mathrm{Cd}$ induced only transient increase in blast frequency (3 weeks), while the fish from $\mathrm{Cu}-1$ group showed significantly elevated level of early blast cells beginning from the 2 weeks of exposure until the end of the experiment.

Similarly, also the frequency of proliferating (PCNA-positive) cells significantly increased in 1 week after short-term exposures (Fig. 3, 4). In Cd-s group, the level of cells undergoing mitosis remained elevated until the 2-week post-exposure, while in $\mathrm{Cu}$-s proliferation rate quickly decreased to the control level. During long-term $\mathrm{Cd}$ exposure, a significant increase in precursor cell proliferation took place in 2 weeks, and their level remained elevated until the end of the experiment. The reaction of fish from $\mathrm{Cu}$-1 group was different: a significant increase in frequency of proliferating cells took place at the end of the experiment (in 4 weeks of exposure).

Both metals induced a significant increase in the frequency of apoptosis of hematopoietic precursor cells (Fig. 5, 6). Both short-term and long-term exposures caused similar effects, but in case of $\mathrm{Cd}$ exposures, the reaction was more pronounced.

These changes resulted in a reduction of hematopoietic potential in all metal-exposed fish, measured as the ratio of frequencies of precursor cell proliferation and apoptosis (Fig. 7). It is noteworthy that in case of short-term copper exposure, reduction in hematopoietic activity at the end of the experiment was deeper than in group subjected to short-term cadmium intoxication or to fish subjected to a long-term copper treatment. However, in all cases, hematopoietic activity was over than 1 showing that the frequency of proliferating cells was all the higher than percentage of precursors undergoing apoptosis.

\section{Discussion}

The obtained results show that cadmium and copper disturbed hematopoiesis in carp but on the other hand indicate a considerable compensatory potential of carp hematopoietic system. The pattern of changes after short-term exposures (a rapid increase in cell proliferation rate and early blast frequency, accompanied by an increase in apoptotic rate) and during long-term treatments (gradual increase in the values of these parameters during the exposures) was different but the final effect-reduction in cell turnover rate was very similar. The increase in apoptotic rate was higher when compared to acceleration of precursor cell proliferation. No anemia was observed in peripheral

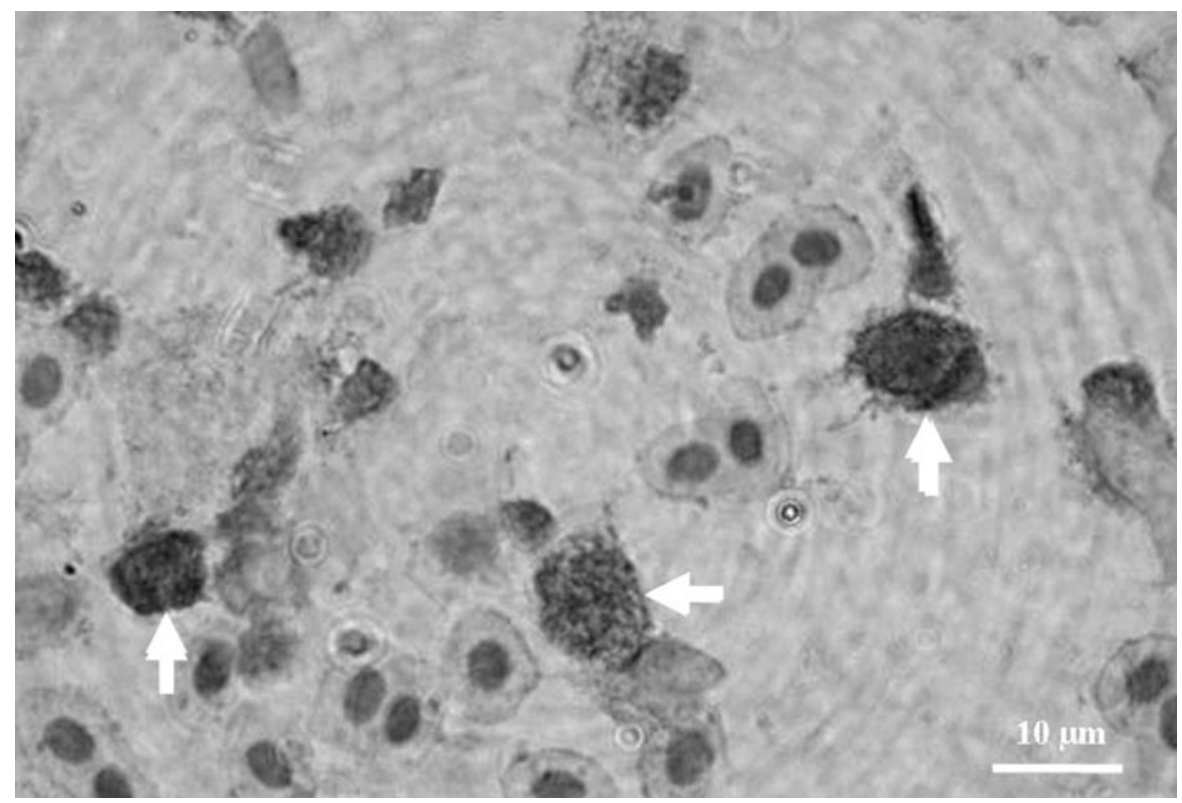

Fig. 4 PCNA-positive cells 

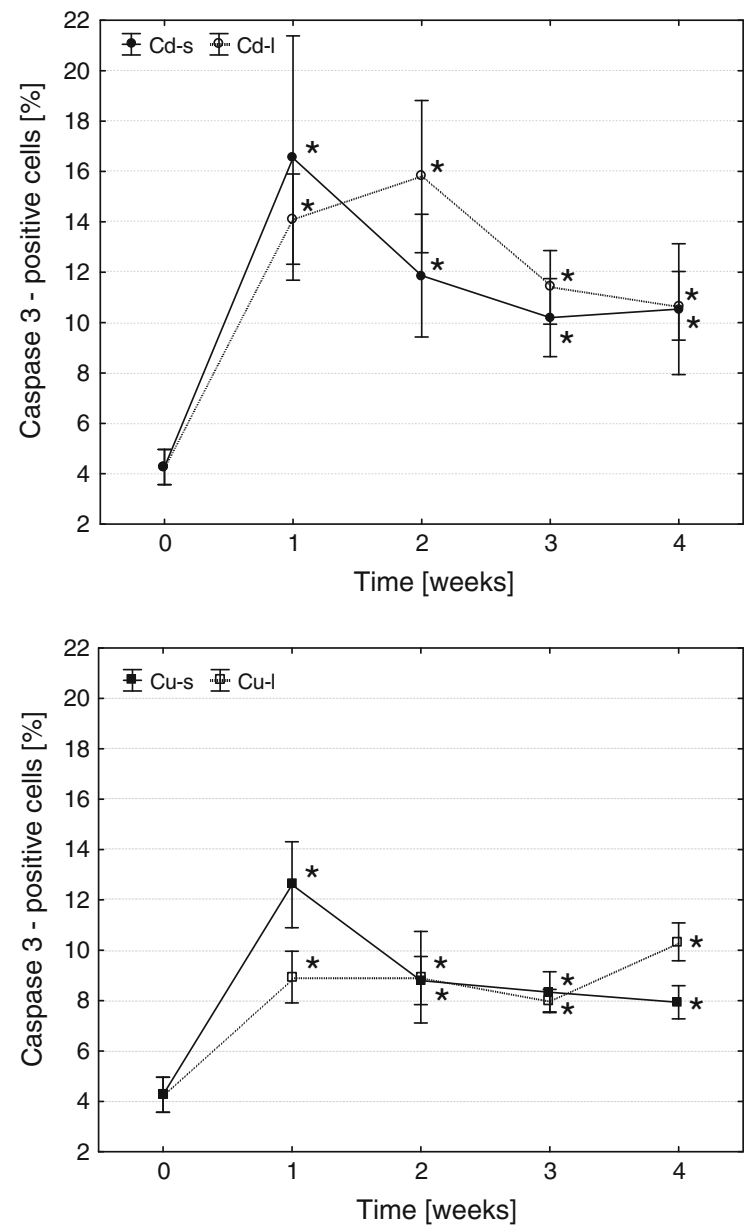

Fig. 5 The effects of $\mathrm{Cd}$ and $\mathrm{Cu}$ on the frequency of apoptotic cells in common carp head kidney hematopoietic tissue (arithmetic mean \pm s.e., *different from the value before metal exposure (time 0), $p \leq 0.05$, U Mann-Whitney test). Cd-s, Cu-s and $\mathrm{Cd}-\mathrm{l}, \mathrm{Cu}-\mathrm{l}-$ groups subjected to short- or long-term exposures, respectively

blood or a significant reduction in leukocyte count, and the most pronounced effect of metal exposures was significantly reduced frequency of peripheral phagocytes (neutrophils and monocytes), accompanied by reduction in their metabolic activity (Kondera and Witeska 2012, and unpublished data of the same study). These results indicate that hematopoietic potential of carp head kidney tissue was reduced due to the increase in apoptotic cell destruction since no necrosis or other visible cell damage was observed.

Hematological effects of heavy metal intoxication of fish were extensively studied, but very little data concerning metal-induced alterations in hematopoietic system are available. According to Garofano and
Hirshfield (1982), 2-h exposure of Ictalurus nebulosus at $61.3 \mathrm{mg} / \mathrm{dm}^{3}$ of Cd resulted in complete destruction and elimination of all hematopoietic precursor cells in head kidney hematopoietic tissue over 24-h postexposure, and the only cells present after intoxication were mature erythrocytes. Also, Saxena et al. (1992) mentioned damage of Heteropneustis fossilis hematopoietic tissue caused by this metal. Considerable hematopoietic disturbances were also observed in Labeo rohita subjected to $\mathrm{Cu}$ treatment: $50 \% 72 \mathrm{hLC}_{50}$ $25 \mathrm{mg} / \mathrm{dm}^{3} \mathrm{Cu}$ or $100 \% 72 \mathrm{hLC}_{50}-50 \mathrm{mg} / \mathrm{dm}^{3} \mathrm{Cu}$ (Som et al. 2009). Sublethal exposure resulted in an increase of abundance of both erythrocyte and leukocyte precursors in head kidney hematopoietic tissue, while under lethal conditions, their number initially decreased, and then increased until the end of the experiment. The authors also observed an increase in blast cell abundance in $\mathrm{Cu}$-exposed fish.

Studies of the effects of metals on hematopoietic tissue of other vertebrates also show their hematotoxic potential. Reduction of hematopoietic potential that resulted in anemia was observed in cadmium-treated rat (Mitsumori et al. 1998). The results of in vitro study revealed that cadmium, lead, and silver adversely affected erythropoiesis in rat bone marrow (Lutton et al. 1984). Van Den Heuvel et al. (1999, 2001) observed that cadmium was more toxic to human and murine hematopoietic progenitor cells than lead, erythroid cell being more sensitive than myeloid precursors. Celik et al. (2005, 2009) reported genotoxic and cytotoxic action of cadmium upon erythroid cells in rat bone marrow.

Almost no data are available on the effects of heavy metals on proliferative and apoptotic activity of fish hematopoietic tissue. The only results were presented by Som et al. (2009) who observed an increase in Labeo rohita blast cell apoptosis during both lethal and sublethal $\mathrm{Cu}$ exposures, while their proliferation rate increased only under sublethal conditions. These results show concentration-related effect of copper on hematopoietic potential of fish.

There are, however, some data showing the effects of cadmium and copper on proliferative and apoptotic activity in other fish tissues. According to Brunelli et al. (2011), cadmium induced increase in proliferation and apoptosis rates in gill epithelium of Thalassoma pavo which was followed by a decrease. Lundebye et al. (1999) reported a significant increase in proliferation and apoptosis rate of intestine 
Fig. 6 Caspase 3-positive cells

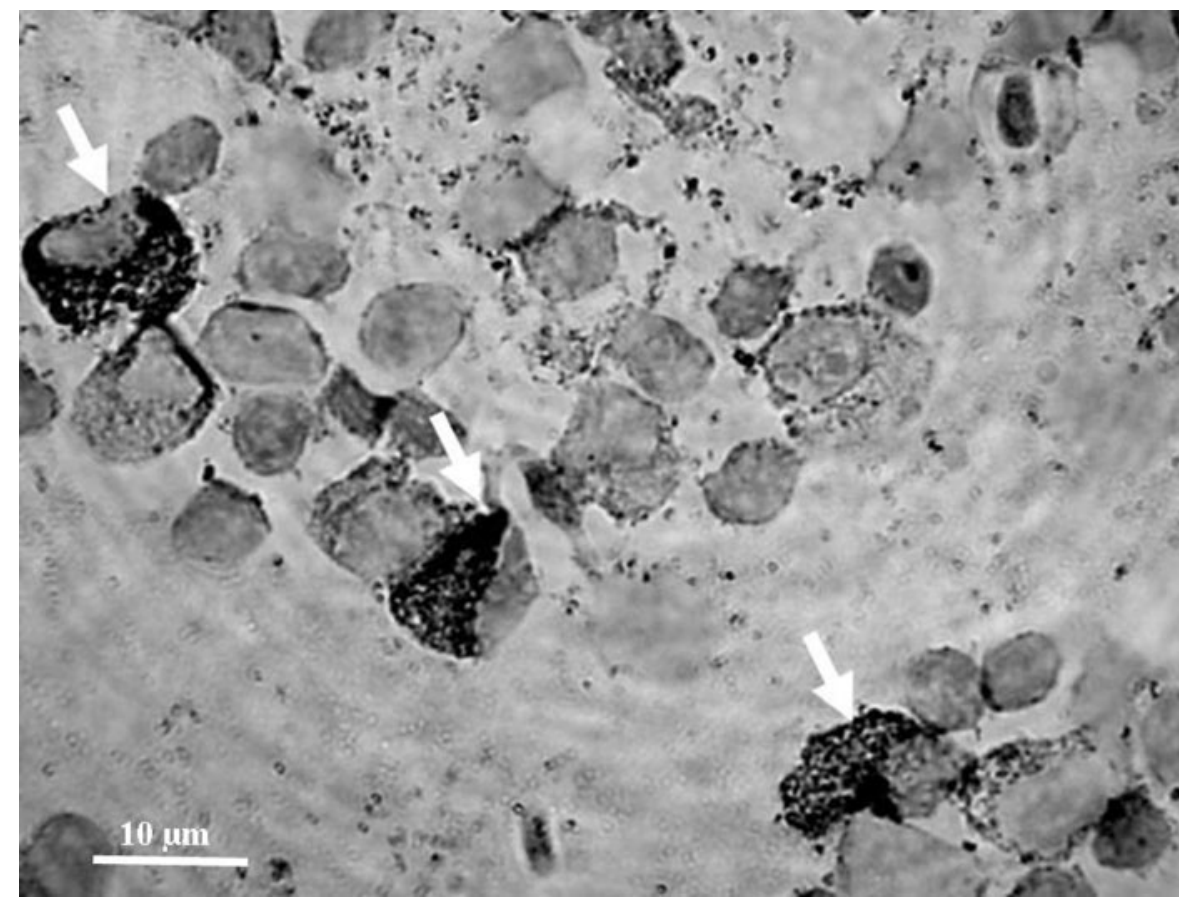

epithelial cells of Salmo salar fed Cd-containing feed. Activation of both cell proliferation and apoptosis in the intestine of Liza aurata from metal-polluted natural environment was also reported by Ferrando et al. (2005). According to Berntssen et al. (2001) and Garcia-Santos et al. (2011), an increase in cell proliferation rate in cadmium-exposed $S$. salar and Sparus aurata may be a protective mechanism reducing adverse effect of metal on fish tissues. According to Hernandez et al. (2011), Danio rerio larvae subjected to $19.5 \mathrm{mg} / \mathrm{dm}^{3}$ of $\mathrm{CuSO}_{4}$ for $2 \mathrm{~h}$ showed an increase in frequency of apoptosis of various types of cells, head kidney cells being more sensitive than brain neurons and gill epithelial cells. Monteiro et al. (2009) reported an increase in proliferation rate of gill epithelial cells in $\mathrm{Cu}$-exposed Oreochromis niloticus which was not accompanied by activation of apoptosis. Massive mitotic activity was detected using PCNA immunostaining in olfactory epithelium of Tilapia mariae following 4-day exposure to $20-100 \mu \mathrm{g} / \mathrm{dm}^{3}$ of $\mathrm{Cu}$ (Bettini et al. 2006). These observations confirm that cell proliferation is involved in tissue regeneration after metal-induced damage.

Metal-induced activation of cell proliferation and apoptosis was reported also in mammals. According to Habeebu et al. (1998), cadmium induced a dose- and time-dependent activation of murine hepatocyte proliferation and apoptosis. Tsangaris and TzortzatouStathoupoulou (1998) observed that cadmium induced apoptosis of human immune cells, B lymphocytes being more sensitive than $\mathrm{T}$ cells and lymphoblasts. Cadmium-induced apoptosis of murine thrombocytes was reported by Fujimaki et al. (2000), and apoptosis of Anas platyrhynchos erythrocytes by Romero et al. (2008).

The data obtained in the present study indicate that cadmium and copper may affect hematological and immune status of fish organism by disturbing the process of hematopoiesis. Hematopoietic precursor cells are sensitive to intoxication and heavy metals enhance the rate of their apoptotic destruction. On the other hand, hematopoietic system of carp shows high homeostatic potential and tends to compensate cell loss by activation of mitotic divisions. The results showed that toxic effects of both metals were persistent and hematopoietic activity reduced after shortterm exposures to cadmium and copper did not recover in 4-week post-treatment. They also showed that low sublethal concentrations of cadmium, and particularly of copper may significantly disturb hematopoietic processes in fish that do not show any other symptoms of intoxication. In conclusion, anemia and 

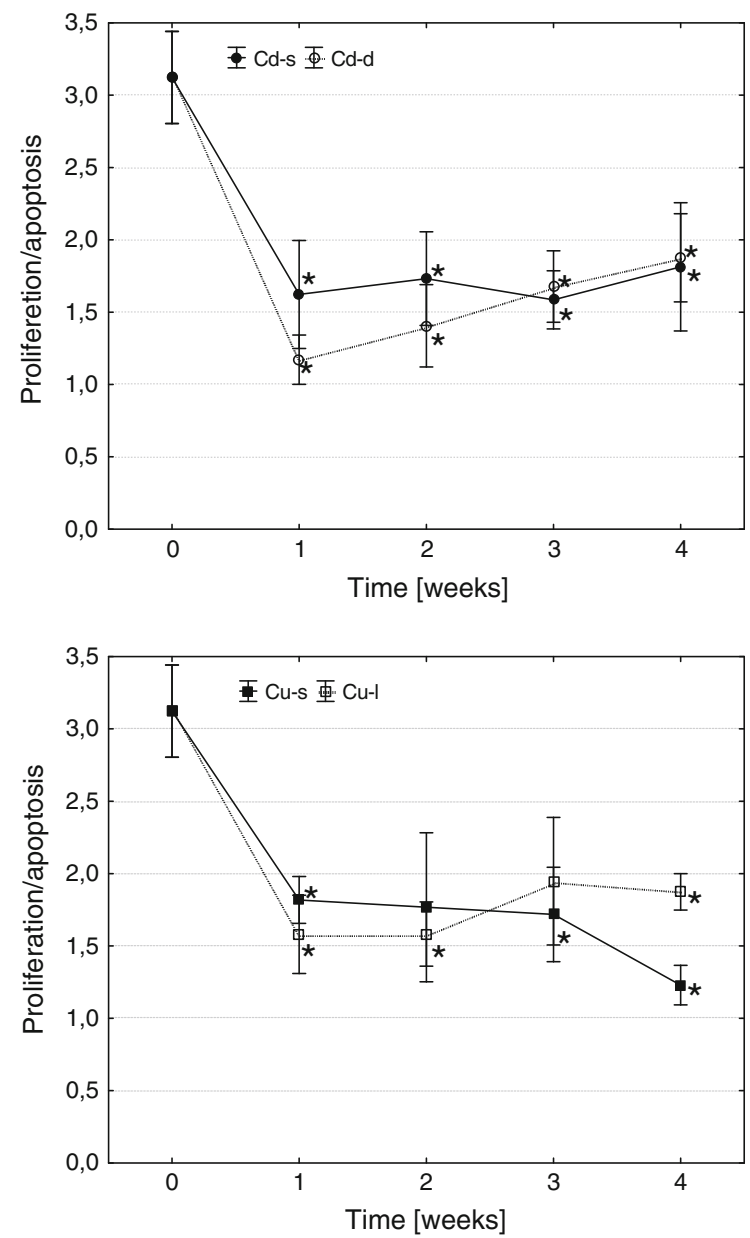

Fig. 7 The effects of $\mathrm{Cd}$ and $\mathrm{Cu}$ on cell turnover rate in common carp head kidney hematopoietic tissue (arithmetic mean \pm s.e., *different from the value before metal exposure (time 0), $p \leq 0.05$, U Mann-Whitney test). Cd-s, Cu-s and Cd-1, $\mathrm{Cu}-\mathrm{l}$-groups subjected to short- or long-term exposures, respectively

immunosuppression often observed in fish intoxicated with copper and cadmium may result from toxic effect of metals on hematopoietic system. Additionally, cellular parameters of hematopoietic tissue: frequency of blast cells and the rate of proliferation and apoptosis are sensitive indicators of sublethal intoxication.

Acknowledgments The study was financed from the grant of Ministry of Science and Higher Education of Poland N N304 002139.

Open Access This article is distributed under the terms of the Creative Commons Attribution License which permits any use, distribution, and reproduction in any medium, provided the original author(s) and the source are credited.

\section{References}

Ates B, Orun I, Talas ZS, Durmaz G, Yilmaz I (2008) Effects of sodium selenite on some biochemical and hematological parameters of rainbow trout (Oncorhynchus mykiss Walbbaum 1792) exposed to $\mathrm{Pb}^{2+}$ and $\mathrm{Cu}^{2+}$. Fish Physiol Biochem 34:53-59

Berntssen MHG, Aspholm OO, Hylland K, Wendelaar Bonga SE, Lundebye AK (2001) Tissue metallothionein apoptosis and cell proliferation responses in Atlantic salmon (Salmo salar L) parr fed elevated dietary cadmium. Comp Biochem Physiol 128C:299-310

Bettini S, Ciani F, Franceschini V (2006) Recovery of the olfactory receptor neurons in the African Tilapia mariae following exposure to low copper level. Aquat Toxicol 76:321-328

Brunelli E, Mauceri A, Maisano M, Bernabo I, Gianetto A, De Domenico E, Corapi B, Tripepi Fasulo S (2011) Ultrastructural and immunohistochemical investigation on the gills of the teleost, Thalassoma pavo L., exposed to cadmium. Acta Histochem 113:201-213

Celik A, Comelekoglu U, Yalin S (2005) A study on the investigation of cadmium chloride genotoxicity in rat bone marrow using micronucleus test and chromosome aberration analysis. Toxicol Ind Health 21:243-248

Celik A, Buyukakilli B, Cimen B, Tasdelen B, Ozturk MI, Eke D (2009) Assessment of cadmium genotoxicity in peripheral blood and bone marrow tissues of male Wistar rats. Toxicol Mech Meth 19:135-140

Dethloff GM, Schlenk D, Khan S, Bailey HC (1999) The effects of copper on blood and biochemical parameters of rainbow trout (Oncorhynchus mykiss). Arch Environ Contam Toxicol 36:415-423

Domen J (2000) The role of apoptosis in regulating hematopoiesis and hematopoietic stem cells. Immunol Res 22:83-94

Drastichova J, Svobodova Z, Luskova V, Machova J (2004) Effect of cadmium on hematological indices of common carp (Cyprinus carpio L). Bull Environ Contam Toxicol 72:725-732

Fange R (1994) Blood cells haemopoiesis and lymphomyeloid tissues in fish. Fish Shellfish Immunol 4:405-411

Ferrando S, Ferrando T, Girosi L, Mauceri A, Fasulo S, Tagliafierro G (2005) Apoptosis, cell proliferation and serotonin immunoreactivity in gut of Liza aurata from natural heavy metal polluted environments: preliminary observations. Eur J Histochem 49:331-340

Fijan N (2002a) Morphogenesis of blood cell lineages in channel catfish. J Fish Biol 60:999-1014

Fijan N (2002b) Composition of main haematopoietic compartments in normal and bled channel catfish. J Fish Biol 60:1142-1154

Fujimaki H, Ishido M, Nohara K (2000) Induction of apoptosis in mouse thymocytes by cadmium. Toxicol Lett 115:99-105

Gangopadhyay K, Homechaudhuri S (2011) Descriptive characteristics of haemopoietic cell lineages in a facultative air breathing fish Clarias batrachus (L). Turk J Zool 35:737-746

Garcia-Santos S, Vargas-Chacoff L, Ruiz-Jarabo I, Varela JL, Mancera JM, Fantainhas-Fernandes A, Wilson JM (2011) 
Metabolic and osmoregulatory changes and cell proliferation in gilthead sea bream (Sparus aurata) exposed to cadmium. Ecotoxicol Environ Saf 74:270-278

Garofano JS, Hirshfield HI (1982) Peripheral effects of cadmium on the blood and head kidney in the brown bullhead (Ictalurus nebulosus). Bull Environ Contam Toxicol 28:552-556

Ghosh D, Datta S, Bhattacharya S, Mazumder S (2007) Longterm exposure to arsenic affects head kidney and impairs humoral immune responses of Clarias batrachus. Aqua Toxicol 81:79-89

Glomski CA, Tamburlin J, Chainani M (1992) The phylogenetic odyssey of the erythrocyte III Fish the lower vertebrate experience. Histol Histopath 7:501-528

Habeebu SSM, Liu J, Klaassen CD (1998) Cadmium-induced apoptosis in mouse liver. Toxicol Appl Pharmacol 149:203-209

Hernandez PP, Undurraga C, Gallardo VE, Mackenzie N, Allende ML, Reyes AE (2011) Sublethal concentrations of waterborne copper induce cellular stress and cell death in zebrafish embryos and larvae. Biol Res 44:7-15

Houston AH, Roberts WC, Kennington JA (1996) Hematological response in fish: pronephric and splenic involvements in the goldfish Carassius auratus L. Fish Physiol Biochem 15:481-489

Joshi PK, Bose M, Harish D (2002) Changes in certain haematological parameters in a siluroid cat fish Clarias batrachus (Linn) exposed to cadmium chloride. Pollut Res 21:129-131

Kobayashi I, Sekiya M, Moritomo T, Ototakeb M, Nakanishia T (2006) Demonstration of hematopoietic stem cells in ginbuna carp (Carassius auratus langsdorfii) kidney. Dev Comp Immunol 30:1034-1046

Kobayashi I, Moritomo T, Ototake M, Nakanishi T (2007) Isolation of side population cells from ginbuna carp (Carassius auratus langsdorfii) kidney hematopoietic tissues. Dev Comp Immunol 31:696-707

Kobayashi I, Kuniyoshi S, Saito K, Moritomo T, Takahashi T, Nakanishi T (2008) Long-term hematopoietic reconstitution by transplantation of kidney hematopoietic stem cells in lethally irradiated clonal ginbuna crucian carp (Carassius auratus langsdorfii). Dev Comp Immunol 32:957-965

Kondera E (2011) Haematopoiesis in the head kidney of common carp (Cyprinus carpio L): a morphological study. Fish Physiol Biochem 37:355-362

Kondera E, Witeska M (2012) Cadmium-induced alterations in head kidney hematopoietic tissue of common carp. Fresenius Environ Bull 21:769-773

Kvasnicka HM, Thiele J, Regn C, Zankovich R, Diehl V, Fischer R (1999) Prognostic impact of apoptosis and proliferation in idiopathic (primary) myelofibrosis. Ann Hematol 78:65-72

Leung AYH, Leung JCK, Chan LYY, Ma ESK, Kwan TT, Lai KN, Meng A, Liang R (2005) Proliferating cell nuclear antigen (PCNA) as a proliferative marker during embryonic and adult zebrafish hematopoiesis. Histochem Cell Biol 124:105-111

Liu Y, Zhang S, Jiang G, Yang D, Lian J, Yang Y (2004) The development of the lymphoid organs of flounder Paralichthys olivaceus from hatching to 13 months. Fish Shellfish Immunol 16:621-632
Lundebye AK, Berntssen MHC, Wendelaar Bonga SE, Maage A (1999) Biochemical and physiological responses in Atlantic salmon (Salmo salar) following dietary exposure to copper and cadmium. Mar Pollut Bull 39:137-144

Lutton JD, Ibraham NG, Friedland M, Levere RD (1984) The toxic effects of heavy metals on rat bone marrow in vitro erythropoiesis: protective role of hemin and zinc. Environ Res 35:97-103

McKenna SL, Cotter TG (1997) Functional aspects of apoptosis in hematopoiesis and consequences of failure. Adv Cancer Res 71:121-164

Migliarini B, Campisi AM, Maradonna F, Truzzi C, Annibaldi G, Scarponi G, Carnevalli O (2005) Effects of cadmium exposure on testis apoptosis in the marine teleost Gobius niger. Gen Comp Endocrinol 142:241-247

Mitsumori K, Shibutani M, Sato S, Onodera H, Nakagawa J, Hayashi Y, Ando M (1998) Relationship between the development of hepato-renal toxicity and cadmium accumulation in rats given minimum to large amounts of cadmium chloride in the long-term: preliminary study. Arch Toxicol 72:545-552

Monteiro SM, dos Santos NMS, Calejo M, Fontainhas-Fernandes A, Sousa M (2009) Copper toxicity in gills of the teleost fish Oreochromis niloticus: effects in apoptosis induction and cell proliferation. Aquat Toxicol 94:219-228

Moritomo T, Asakura N, Sekiya M, Ototake M, Inoue Y, Nakanishi T (2004) Cell culture of clonal ginbuna crucian carp hematopoietic cells: differentiation of cultured cells into erythrocytes in vivo. Dev Comp Immunol 28:863-869

Mulero I, Chaves-Pozo E, García-Alcazar A, Meseguer J, Mulero V, García Ayala A (2007) Distribution of the professional phagocytic granulocytes of the bony fish gilthead seabream (Sparus aurata L) during the ontogeny of lymphomyeloid organs and pathogen entry sites. Dev Comp Immunol 31:1024-1033

Patel S, Sorhus E, Uglenes Fiksdal I, Gunnar Espedal P, Bergh O, Magne Rodseth O, Morton HC, Helge Nerland A (2009) Ontogeny of lymphoid organs and development of IgMbearing cells in Atlantic halibut (Hippoglossus hippoglossus L). Fish Shellfish Immunol 26:385-395

Romano N, Ceccariglia S, Mastrolia L, Mazzini M (2002) Cytology of lymphomyeloid head kidney of Antarctic fishes Trematomus bernacchii (Nototheniidae) and Chionodraco hamatus (Channicthyidae). Tissue Cell 34: 63-72

Rombout JHWM, Huttenhuis HBT, Picchietti S, Scapigliati G (2005) Phylogeny and ontogeny of fish leucocytes. Fish Shellfish Immunol 19:441-455

Romero D, Hernandez-García A, Tagilati CA, Martinez-Lopez E, Garcia-Fernandez AJ (2008) Cadmium- and leadinduced apoptosis in mallard erythrocytes (Anas platyrhynchos). Ecotoxicol Environ Saf 72:37-44

Ruparelia SG, Verma Y, Saiyed SR, Rawall UM (1990) Effect of cadmium on blood of tilapia Oreochromis mossambicus (Peters) during prolonged exposure. Bull Environ Contam Toxicol 45:305-312

Santos AA, Gutierre RC, Antoniazzi MM, Ranzani-Paiva MJT, Silva MRR, Oshima CTF, Egami MI (2011) Morphocytochemical immunohistochemical and ultrastructural characterization of the head kidney of fat snook Centropomus parallelu. J Fish Biol 79:1685-1707 
Saxena MP, Gopal K, Jones W, Ray PK (1992) Immune responses to Aeromonas hydrophila in cat fish (Heteropneustis fossillis) exposed to cadmium and hexachlorocyclohexane. Bull Environ Contam Toxicol 48:194-201

Seong-Gil K, Jae-Won K, Ju-Chan K (2004) Effect of dietary cadmium on growth and haematological parameters of juvenile rockfish Sebastes schlegeli (Hilgendorf). Aquacult Res 35:80-86

Shah SL, Altindag A (2005) Alterations in the immunological parameters of tench (Tinca tinca L 1758) after acute and chronic exposure to lethal and sublethal treatments with mercury cadmium and lead Turk. J Anim Sci 29:1163-1168

Som M, Kundu N, Bhattacharyya S, Homechaudhuri S (2009) Evaluation of hemopoietic responses in Labeo rohita Hamilton following acute copper toxicity. Toxicol Environ Chem 91:87-98

Svobodova ZB, Vykusova B, Machova J (1994) The effects of pollutants on selected haematological and biochemical parameters in fish. In: Muller R, Lloyd R (eds) Sublethal and chronic effects of pollutants on freshwater fish. FAO Blackwell Science, New York, pp 39-52

Thiele J, Zirbes TK, Lorenzen J, Kvasnicka HM, Scholz S, Erdman A, Flucke U, Diehl V, Fischer R (1997) Hematopoietic turnover index in reactive and neoplastic bone marrow lesions: quantification by apoptosis and PCNA labelling. Ann Hematol 75:33-39

Tsangaris GT, Tzortzatou-Stathoupoulou F (1998) Cadmium induces apoptosis differentially on immune system cell lines. Toxicology 128:143-150

Van Den Heuvel RL, Leppens H, Schoeters GER (1999) Lead and catechol hematotoxicity in vitro using human and murine hematopoietic progenitor cells. Cell Biol Toxicol 15:101-110

Van Den Heuvel RL, Leppens H, Schoeters GER (2001) Use of in vitro assays to assess hematotoxic effects of environmental compounds. Cell Biol Toxicol 17:107-116

Vosyliene MZ (1999) The effect of heavy metals on hematological indices of fish (survey). Acta Zool Lituanica Hydrobiologia 9:76-82

Wendelaar Bonga SE (1997) The stress response in fish. Physiol Rev 77:591-625

Weyts FAA, Cohen N, Flik GB, Verburg-Van Kemenade ML (1999) Interactions between the immune system and the hypothalamo-pituitary-interrenal axis in fish. Fish Shellfish Immunol 9:1-20

Witeska M, Kondera E, Lipionoga J, Nienałtowska R (2009) The changes in blood leukocyte profile of common carp induced by acute exposures to copper and cadmium. Fresenius Environ Bull 18:1534-1540

Witeska M, Kondera E, Lipionoga J, Jastrzębska A (2010) Changes in oxygen consumption rate and red blood parameters in common carp Cyprinus carpio $\mathrm{L}$ after acute copper and cadmium exposures. Fresenius Environ Bull 19:115-122

Yousaf MN, Koppang EO, Skjodt K, Kollner B, Hordvik I, Zou J, Secombes J, Powell MD (2012) Cardiac pathological changes of Atlantic salmon (Salmo salar L) affected with heart and skeletal muscle inflammation (HSMI). Fish Shellfish Immunol 33:305-315

Zapata A, Diez B, Cejalvo T, Gutierrez-de Frias C, Cortes A (2006) Ontogeny of the immune system of fish. Fish Shellfish Immunol 20:126-136. http://www.pwik.siedlce.pl 